Acta Universitatis Wratislaviensis No 3948

PRAWO CCCXXVIII

Wrocław 2019

DOI: $10.19195 / 0524-4544.328 .5$

\author{
JOANNA MACHUT-KOWALCZYK \\ ORCID: 0000-0003-0733-7709 \\ Uniwersytet Łódzki \\ jmachut-kowalczyk@wpia.uni.lodz.pl
}

\title{
Dokumentowanie śledztwa allewiacyjnego (po gradobiciu albo powodzi) w Królestwie Polskim na podstawie akt naczelników powiatu do 1866 roku
}

\section{Wstęp}

Zagadnienie allewiacji ${ }^{1}$ i procedura rozstrzygania wniosków opisana została przez W. Witkowskiego w pracy o funkcjonowaniu sądownictwa administracyjnego w Księstwie Warszawskim i Królestwie Polskim² ${ }^{2}$ Jednak śledztwo allewiacyjne prowadzone od 1842 roku przez naczelnika powiatu opracowano jedynie w zakresie zagadnienia odbierania przysięgi ${ }^{3}$. Do zbadania pozostała

1 Allewiacja była ulgą w podatkach dla dóbr, w których gradobicia, powódź, pożar lub działania wojenne spowodowały szkody. Wymiar ulgi zależał od wysokości i rodzaju poniesionych strat. Prawo regulowało zasady, według których miała być przyznana ulga, na przykład Postanowienie Królewskie z 17 grudnia 1810 r., Postanowienie Rady Ministrów z 28 Listopada 1812 r., Postanowienie tworzące Delegacye Administracyjne, do ostatecznego rozstrzygania sporów wynikających z żądania allewiacyi z 20 lutego 1816 r., Rozporządzenie w przedmiocie przyznawania allewiacyi za klęskę wojny z 1 lutego 1832 r., Instrukcja do spraw allewiacyjnych przez Kommissyą Rządową Przychodów i Skarbu wydana w roku 1844, Postanowienie przepisujące termin na doniesienie o klęsce w celu przyznania allewiacyi z 1 (13) sierpnia 1850 roku itp. Przepisy administracyjne ujęto w osobnym tomie (Zbiór Przepisów Administracyjnych Królestwa Polskiego, Wydziat Skarbu, t. 2. Allewiacje, Warszawa 1866 [dalej: ZPAKP, W.Sk., Allewiacje]).

2 W. Witkowski, Sąownictwo administracyjne w Księstwie Warszawskim i Królestwie Polskim 1807-1867, Warszawa 1984, s. 113-115, 155-156.

3 J. Machut-Kowalczyk, Przysięga w śledztwie allewiacyjnym w Królestwie Polskim w świetle akt powiatowych wieluńskich, zamojskich i łukowskich, „Studia z Dziejów Państwa i Prawa Polskieअo"20 328, 2019 183-204.

(C) for this edition by CNS 
między innymi praktyka dokumentowania akt w ramach tego postępowania, co jest przedmiotem przedstawianego studium.

Ponieważ dopiero utrata dwóch trzecich dochodu uprawniała poszkodowanego do uzyskania allewiacji, śledztwo miało na celu ustalenie strat, jakich na skutek klęski poszkodowany doznał w rocznym dochodzie. Ważne było też ustalenie, czy i w jakiej wysokości ubiegający się o allewiację opłacił podatek. W sprawach wynikających z gradobicia albo powodzi postępowanie dzielono na dwa etapy: przedwstępny i ostateczny. Śledztwo uzupełniające miało miejsce jedynie w przypadku wszczęcia postępowania w drugiej instancji ${ }^{4}$.

Akta allewiacyjne znajdujemy w pięciu zespołach akt powiatowych zachowanych w Sieradzu (Naczelnik Powiatu Wieluńskiego: nr zespołu 717/0), Lublinie (Naczelnik Powiatu Zamojskiego: nr zespołu 127/0, Naczelnik Powiatu Łukowskiego: nr zespołu 125/0), Kaliszu (Naczelnik Powiatu Kaliskiego: nr zespołu: 1/0) i Łodzi (Naczelnik Powiatu Piotrkowskiego: nr zespołu 37/0) ${ }^{5}$. Dokumentację śledczą zawierano z reguły w ,aktach szczegółowych"6. Dokumentują one śledztwa wszczęte w związku z klęskami gradobicia albo powodzi ${ }^{7}$. Pozostałe trzy zespoły to ,akta generalne”, zawierające instrukcje i ogólne pouczenia co do formułowania akt. Niektóre z nich zawierają w sobie szczątki akt szczegółowych ${ }^{8}$.

W archiwach zachowały się wcześniejsze instrukcje i wytyczne władz rządowych $^{9}$ i wojewódzkich (gubernialnych), dotyczące dokumentowania śledztwa al-

4 Zob. ibidem, s. 186-187.

5 W Archiwum Państwowym w Łodzi w inwentarzu zespołu „Naczelnik Powiatu Piotrkowskiego" znajduje się jedna sygnatura dokumentująca allewiację, ale ze względu na bardzo zły stan nie jest udostępniana.

${ }^{6}$ Archiwum Państwowe w Łodzi oddział w Sieradzu: APŁ, Naczelnik Powiatu Wieluńskiego: sygn.1, „Akta tyczące się Allewiacyi dla Gminy Borowno. Z przyczyny klęski gradobicia i pożarów oraz wylewu rzek — podatki ulegały Allewiacyi tj. prolongacie a nawet i umorzeniu długu" (dalej: APŁ/S, NPW, sygn. 1); sygn. 3, „Akta w sprawie allewiacji dla gminy Kłomnic” (dalej: APŁ/S, NPW, sygn. 3); Archiwum Państwowe w Lublinie, Naczelnik Powiatu Łukowskiego, sygn. 275, „Akta szczegółowe Naczelnika Powiatu Łukowskiego tyczące się Allewiacyi” (dalej: APL, NPŁ, sygn. 275).

$7 \mathrm{~W}$ aktach przewijają się pojedyncze dokumenty tyczące się pożarów (z lat 1843-1866). Nie są one jednak kompletne, przez co nie można na ich podstawie określić sposobu ich dokumentowania. Dlatego zrezygnowałam z uwzględnienia ich w tej pracy. Istotne były także odmienne zasady ich prowadzenia.

8 Archiwum Państwowe w Lublinie: Naczelnik Powiatu Zamojskiego: sygn. 18, „Akta generalne tyczące się Bodaczowa wsi Allewiacyi” (dalej: APL, NPZ, sygn. 18); sygn. 19, „Akta generalne tyczące się Czarny Stok wsi Allewiacyi” (dalej: APL, NPZ, sygn. 19); APL, Naczelnik Powiatu Łukowskiego, sygn. 1, „Akta generalia Allewiacyi” (dalej: APL, NPŁ, sygn.1). W Archiwum Państwowym w Kaliszu zachowała się jednostka zespołu Naczelnik Powiatu Kaliskiego: sygn. 239, „Akta ogólne podawania allewiacyi” (dalej: APK, NPK, sygn. 239). Dokumentacja ta nie zawiera akt śledczych, lecz jedynie interesującą korespondencję organów administracyjnych w sprawie dokumentowania śledztwa allewiacyjnego.

9 Reskrypty i polecenia władz rządowych były przesyłane na szczebel obwodowy (powiatowy) za pośrednictwem władz wojewódzkich (gubernialnych). Na przykład „Kopia reskryptu Komisji Rządowej Przychodów i Skarbu do Komisji Województwa Kaliskiego z 11 marca 1834 r.” (APK, NPK, sygn. 239, s. 25-28). Podobnie ibidem, s. 41-42 (1836 rok), s. 65-67 (1841 rok).

Prawo 328, 2019

(C) for this edition by CNS 
lewiacyjnego ${ }^{10}$. Znajdujemy między innymi informację, jak akta powinny wyglądać ${ }^{11}$ : miały być foliowane (numerowane), powinny zawierać wykaz zawartych w nich treści, sumariusz zawartych dowodów i być zszyte, a na zewnątrz opatrzone obwolutą ${ }^{12}$. Natrafiamy na uwagi o nieodpowiednim redagowaniu akt ${ }^{13}$, informacje o pomyłkach rachunkowych ${ }^{14}$. Podsędkowie urzędujący w sądach pokoju zwracali też uwagę na nieodpowiednią formę spisywanych zeznań ${ }^{15}$. Rządy gubernialne starały się również monitorować toczące się postępowania. Żądały między innymi informacji o toczących się w powiatach śledztwach allewiacyjnych ${ }^{16}$.

10 Rząd Gubernialny Podlaski do KO (zwraca się do Naczelnika Powiatowego już) Łukowskiego (z Wydziału Skarbu) z polecenia gubernatora cywilnego radca nadzwyczajny, za sekretarza 20 listopada-1 grudnia 1842 roku Prowadzenie śledztwa wytyczne. APL, NPŁ, sygn. 1, k. 45-46.

11 Komisja Województwa Podlaskiego do Komisarza Obwodu Łukowskiego (z Wydziału Skarbu). Podpisany prezes i sekretarz 21 lutego 1833 roku przesyła w odpisie reskrypt kom. Rz. Przychodów i skarbu przewidujący sposób formułowania akt allewiacyjnych. Poleca, aby akta allewiacyjne były zgodnie z tym kompletowane. Reskrypt z 15 lutego 1833 roku. APL, NPŁ, sygn. 1, k. 24-27; RGL przesyła NPŁ kopię reskryptu dla NP. Siedleckiego co do formułowania akt allewiacyjnych 26 lipca-8 sierpnia 1849 roku. APL, NPŁ, sygn.1, k. 57.

12 APL, NPE, sygn.1, k. 19 (1827 rok).

13 Komisja Województwa Podlaskiego pisała do Komisarza Obwodu Łukowskiego 18 maja 1833 roku. Zwróciła mu uwagę na nieodpowiednie formułowanie akt allewiacyjnych (APL, NPŁ, sygn.1, k. 28). Podobnie Komisja Województwa Kaliskiego wyliczyła 19-31 października 1836 roku najczęściej pojawiające się błędy: niedokumentowanie całości śledztwa, niezałączanie tabel allewiacyjnych, świadectw kas obwodowych, o opłacanych przez poszkodowanych podatkach, brak podpisu komisarzy delegowanych do obwodu, niefoliowanie i niezszywanie akt śledczych itp. (APK, NPK, sygn. 239, s. 53). Poniżej pouczyła komisarza obwodowego, że w razie dostrzeżenia ponownie tego rodzaju uchybień w aktach śledczych będzie groziła mu kara „Złłp 10 albo też akta całkowite [...] na koszt sobie będzie miał zwrócone" (s. 54).

14 Komisja Województwa Podlaskiego przesłała do Komisarza Obwodu Łukowskiego 10-22 października 1836 roku pismo informujące o pomyłkach rachunkowych w protokołach z śledztwa alewiacyjnego prowadzonego przez komisarzy obwodowych, o obowiązku przedstawienia do sprawdzenia rachunków rachmistrzowi pod rygorem kary (APL, NPŁ, sygn.1, Akta generalia Allewiacyi, k. 31). Podobnie APK, NPK, sygn. 239, s. 53-54 (1836 rok).

15 J. Machut-Kowalczyk, op. cit., s. 199.

16 Wzór takiego raportu znajdujemy w aktach Naczelnika Powiatu Kaliskiego „Wykaz Spraw Alewiacyinych Rządowi Gubernialnemu przedstawić się mających”. Tabela miała zawierać podzielone na rubryki informacje: „Dóbr Ziemskich i Miast”, „Gminy”, „Rodzaj klęski”, „Data klęski”, „Nazwisko poszkodowanych kontrybuentów”, datę zgłoszenia się lub datę i numer dyspozycji RG zarządzającej śledztwo (s. 113-114). Przesłana została wraz ze szczegółowym uzasadnieniem RGW z 1-13 lutego 1847 roku, w którym między innymi czytamy: „dostrzegać się daje, że czynności tego rodzaju zwykle przez delegowanych do ich wykończenia długi czas przetrzymywane bywają, jako też, że niekiedy przedmioty te w biórze[!] Naczelnika $\mathrm{P}^{\text {tu }}$ doznają zwłoki — z tego wynika, że gdy według przepisów spodziewana allewiacya nie wstrzymuje poboru podatków allewiowanemi być mających". NPK w swoim raporcie z 8-20 marca 1847 roku do Rządu Gubernialnego Warszawskiego napisał: „Ma honor donieść Rządowi Gubernialnemu iż w Powiecie tuteyszym żadne Śledztwa, tak do wyprowadzenia lub przedstawienia o uzyskanie allewiacyi z powodu poniesionych Klęsk nie zalegaią" (s. 115). 
Czynności śledcze wpływały na powstawanie różnego rodzaju dokumentów. Wśród nich warto wskazać najważniejsze: raport w sprawie wystąpienia klęski, protokół allewiacyjny, wykaz opłaconych podatków i protokół odebrania przysięgi od poszkodowanych i świadków. Te dokumenty składały się na akta śledztwa allewiacyjnego. Postaram się scharakteryzować każdy z nich.

\section{Raport w sprawie wystąpienia klęski}

Raport w sprawie wystąpienia klęski zdawał Naczelnikowi Powiatu (dalej: NP) miejscowy urzędnik. Na jedenaście tego rodzaju dokumentów, autorem ośmiu był wójt ${ }^{17}$, w jednym przypadku burmistrz (wcześniej jednak i tu swój raport złożył wójt $)^{18}$. W dwóch przypadkach informacja o klęsce pochodziła od poszkodowanego ${ }^{19}$.

Reskrypt Komisji Rządowej Przychodów i Skarbu (dalej: KRPiS) z 1830 sierpnia 1836 roku nakazywał, by urzędnik w ciągu trzech dni od gradobicia przybył na grunt, potwierdził wystąpienie kataklizmu i przekonał się o powstałych szkodach $^{20}$. Według instrukcji w sprawach allewiacyjnych z 18-30 stycznia 1845 roku, wydanej przez KRPiS, poszkodowany miał obowiązek zażądać śledztwa najpóźniej 14 dni po wystąpieniu klęski żywiołowej ${ }^{21}$. Artykuł 1 postanowienia Rady Administracyjnej z 1-13 sierpnia 1850 roku określał ten termin na 30 dni po zdarzeniu, liczonych w przypadku powodzi ,od dnia, w którym wody z miejsc zalanych ustąpiły"22. W praktyce najczęściej raport wysyłany był w ciągu jednego-dwóch dni po klęsce ${ }^{23}$, rzadziej kilka dni po szkodzie ${ }^{24}$.

W aktach z powiatu kaliskiego z 1844 roku natrafiamy na przypadek powodzi, która wyrządziła wiele szkód (wydany został nawet reskrypt zawieszający pobór podatków na trzy miesięce ${ }^{25}$ ). Mimo to poszkodowani nie zażądali

17 APŁ/S, NPW, sygn. 3, k. 29 (1849 rok); 37 (1850 rok), 39 (1855 rok); APL, NPZ, sygn. 18, k. 30 (1845 rok); APL, NPŁ, sygn. 275, k. 12 (1863 rok), 34 (1864 rok), 35, 43 (1858 rok).

18 APŁ/S, NPW, sygn. 3, k. 28.

19 APŁ, NPE, sygn. 275, k. 77, 88 (1865 rok).

20 APL, NPŁ, sygn. 1, k. 29-30.

21 Rząd Gubernialny Podlaski przytacza treść instrukcji: ,,pod utratą prawa do niej natychmiast a najdalej w ciągu dni 14. zażądać sprawdzenia z Klęski”. APL, NPŁ, sygn. 1, k. 49. Podobnie uczynił Rząd Gubernialny Warszawski 1-13 marca 1845 roku. APK, NPK, sygn. 239, s. 107-109.

22 Kopia postanowienia RA z 1-13 sierpnia 1850 roku. APL, NPE, sygn. 1, Akta Generalia Allewiacyi, k. 60. Podobnie APK, NPK, sygn. 239, s. 119-120.

23 APŁ/S, NPW, sygn. 3, k. 28-29 (1849 rok), 37 (1850 rok), 39 (1855 rok); APL, NPZ, sygn. 18, Akta generalne tyczące się Bodaczowa wsi Allewiacyi, k. 30 (1845 rok); APL, NPŁ, sygn. 275, k. 77-78.

24 APŁ, NPŁ, sygn. 275, k. 12 (1863 rok), 34 (1864 rok), 35, 42-43 (1858 rok).

$25 \mathrm{~W}$ wypisie z protokołu posiedzenia Rady Administracyjnej dnia 24 listopada-6 grudnia 1844 roku czytamy: „Wydanie wskutek decyzyi Rady Administracyinej z dnia 4-16 sierpnia r. b. 
wytoczenia śledztwa ${ }^{26}$. Raport informował o okolicznościach kataklizmu i jego skutkach $^{27}$. Pod koniec znajdowała się prośba o zainicjowanie śledztwa ${ }^{28}$.

30 maja-11 czerwca 1845 roku Wójt Gminy Biszczy informuje NPZ o silnym gradobiciu i złej sytuacji gospodarzy. W treści raportu czytamy: „, [...] w zeszłym roku powodzie i wylewy wód, w tym roku na obsiewy zmuszeni byli wyprzedać swój inwentarz dziś po klęsce są znowu pozbawieni w zupełności sposobu wyżywienia i dalszego prowadzenia gospodarstwa"29.

W jednym przypadku znalazłam dwa raporty dokumentujące to samo zdarzenie $^{30}$. Raport Burmistrza Mstowa był mniej szczegółowy, napisany w dniu klęski. Dokument sporządzony przez Wójta Kłomnic spisany został dzień po klęsce, 6-18 czerwca 1849 roku, i opisywał dość szczegółowo przebieg samego gradobicia i ogólnie straty:

W dniu wczorajszym o godzinie 6 z południa w Gminie Kłomnice w[e] wsi tejże i na Michałowie folwarku Xiężym przy powstałej burzy połączonej z gwałtownym wichrem spadł grad wielkości orzecha włoskiego, a miejscami Kurzego jaja, Któren poczynił znaczne szkody tak w budynkach przez obalenie i uszkodzenie onych jako też w zbożu, a szczególniej oziminie zniszczywszy przez połowę zasiewy i zbiory, tak dworskie jako i włościańskie — o czem Wójt Gminy ma honor złożyć rapport ${ }^{31}$.

\section{Protokół allewiacyjny}

Kolejnym dokumentem był protokół allewiacyjny, który sporządzano na polecenie naczelnika powiatu ${ }^{32}$. 29 czerwca-11 lipca 1849 roku Rząd Gubernialny Lubelski po skargach właścicieli poszkodowanych gradobiciem z 5-17 czerwca 1849 roku wystosował do Naczelnika Powiatu Łukowskiego pouczenie:

rozporządzenia względem zawieszenia exekucyi podatków skarbowych do trzech miesięcy poszkodowanym wskutek tegorocznych powodzi, miały głównie na celu przyniesienie tymże poszkodowanym chwilowej ulgi, tudzież aby im pozostawić pewny przeciąg czasu potrzebny do usprawiedliwienia za pomocą miejscowego śledztwa prawa do allewiacyi”. APK, NPK, sygn. 239, s. 103.

26 W raporcie NPK z 21 lutego-5 marca 1845 roku czytamy: „Żadne też środki co do uzyskania allewiacyi przedsiębrane bydź nie mogły, bo nikt o takową nie zgłosił się i z pewnością nikt allewiacyi żądać nie będzie. Spodziewać się należy, że skoro zasiewy oziminne w zupełności są dopełnione to i jarzynne uzupełnić potrafią bowiem dotąd N. P. nie odebrał od nikogo rapportu aby na czemkolwiek zbywać miało, jednak [...] starać się będzie powziąść pewne wiadomości”. APK, NPK, sygn. 239, s. 106.

27 APŁ/S, NPW, sygn. 3, k. 39; APŁ, NPŁ, sygn. 275, k. 12 (1863 rok), k. $42-43$ (1858 rok).

28 APŁ, NPŁ, sygn. 275, k. 12 (1863 rok), k. 42-43 (1858 rok).

29 APL, NPZ, sygn. 18, k. 30-31.

30 APE/S, NPW, sygn. 3, k. 28-29.

31 APŁ/S, NPW, sygn. 3, k. 29.

32 APŁ/S, NPW, sygn. 1, k. 122; APŁ/S, NPW, sygn. 3, k. 30-31; APL, NPŁ, sygn. 275, k. 3, $15,44-45$. 
poleca Naczelnikowi Ptu Łukowskiego, ażeby na każde zgłoszenie się Właściciela dóbr Ziemskich którego klęska gradobicia dotknęła za pomocą śledztwa na grunt zesłać się powinnego, przekonywał się o wysokości strat poniesionych w obsiewach ozimych i jarych ${ }^{33}$.

Artykuł 2 postanowienia Rady Administracyjnej z 1-13 sierpnia 1850 roku przewidywał, że naczelnik powiatu miał 14 dni na zarządzenie sprawdzenia klęski na miejscu ${ }^{34}$.

Dokument był różnorodnie tytułowany: „Protoku[ó]ł obliczenia Szkody przez Gradobicie w Dobrach Borowno Powiecie Wieluńskim z r. 1849”35, „Interes allewiacyjny”36, „Protokół administracyjny”37, „Protokół Wizji”38.

Protokoły oględzin miejsca ${ }^{39}$ klęski sporządzali z reguły urzędnicy lokalni ${ }^{40}$. Poza burmistrzami i wójtami sporządzenie protokołu administracyjnego naczelnik powiatu zlecał innym osobom (na przykład rachmistrzowi biura $\mathrm{NP}^{41}$, sekretarzowi biura $\mathrm{NP}^{42}$, kasjerowi miasta ${ }^{43}$ ).

Urzędnicy miejscowi sporządzali ten dokument w swoich kancelariach ${ }^{44}$, inni w kancelariach miejscowych urzędników lub na miejscu zdarzenia ${ }^{45}$. Wizja następowała $\mathrm{w}$ ciągu tygodnia ${ }^{46}$ lub do kilku tygodni po klęsce ${ }^{47}$.

Protokół miał zawierać szczegółowy opis strat w dobrach, które ucierpiały w trakcie klęski. Różnorodność materiału źródłowego sprawia wrażenie, że urzęd-

33 APL, NPŁ, sygn. 1, k. 55.

34 Art. 2 stanowił: „Naczelnicy Powiatowi, tudzież Magistrat Miasta Warszawy, po otrzymaniu doniesienia o jednej z powyższych klęsk, obowiązani są zarządzić sprawdzenie jej na miejscu, najdalej w ciągu dni czternastu". ZPAKP, W.Sk., Allewiacje, s. 155. Postanowienie przepisujące termin na doniesienie o klęsce w celu przyznania allewiacyi, z 1 (13) sierpnia $1850 \mathrm{r}$.

35 APŁ/S, NPW, sygn. 1, k. 123.

36 APŁ/S, NPW, sygn. 3, k. 30, 34 (1849 rok).

37 Np. APŁ/S, NPW, sygn. 3, k. 30-32, 34-35 (1849 rok); APL, NPŁ, sygn. 275, k. 8 (1862 rok).

38 APŁ, NPŁ, sygn. 275, k. 15 (1863 rok), k. 78 (1865 rok).

39 Procedura cywilna również przewidywała środek dowodowy tego rodzaju. Zob. „Tytuł VIII. O naocznem obejrzeniu miejsc i o ocenieniu" (art. 41-43), Kodex Postępowania Cywilnego"; S. Zawadzki, Prawo cywilne obowiazującem w Królestwie Polskiem, t. 2, Warszawa 1861, s. 185-186.

40 Protokół z 29 września 1849 roku sporządzony w Urzędzie Wójta Gminy Borowna, APŁ/S, NPW, sygn. 1, k. 123-133. Podobnie APL, NPŁ, sygn. 275, k. 2-4 (lata 1861-1862); APL, NPŁ, sygn. 275, k. 15 (1863 rok); APŁ/S, NPW, sygn. 3, k. 30-32 (1849 rok).

41 Np. APL, NPŁ, sygn. 275, k. 14 (1863 rok), 88-89 (1865 rok).

42 APŁ, APL, NPŁ, sygn. 275, k. 44-45(1858 rok), k. 78 (1865 rok).

43 APŁ/S, NPW, sygn. 3, k. 33 (1850 rok), 34-35 (1849 rok).

44 Ibidem, k. 30, 33, 34-35; APŁ/S, NPW, sygn. 1, k. 123; APL, NPŁ, sygn. 275, k. 14 (1861 rok), k. 15 (1863 rok).

45 APŁ/S, NPW, sygn. 3, k. 33 (1850 rok); APL, NPŁ, sygn. 275, k. 2 (spisany w Dobrach Ławki, protokół Wizji z 10-22 czerwca 1861 roku — informacja w świadectwie NPŁ), k. 44-45 (1858 rok), k. 78 (1865 rok).

46 Dzień po klęsce (APL, NPŁ, sygn. 275, k. 2-3), 3 dni po (k. 88-89), 5 dni po niej (k. 15).

47 APL, NPŁ, sygn. 275, k. $78-8-20$ lipca 1865 rok (10 dni po); APŁ/S, NPW, sygn. 3, k. 33 - 2-14 czerwca 1850 rok (12 dni po); 28 dni po klęsce (ibidem, k. 30). Drugi dzień wcześniej (2-14 lipca 1849 rok — ibidem, s. 34-35). Inny przykład APL, NPŁ, sygn. 275, k. 44-45-22 dni po (1858 rok).

Prawo 328, 2019

(C) for this edition by CNS 
nicy nie do końca wiedzieli, jak taki protokół powinien wyglądać. Trzeba jednak pamiętać, że materiał, którym dysponujemy, zachował się szczątkowo. Akta dokumentują jedynie dziesięć protokołów (z lat 1843-1866).

W materiale archiwalnym nie brakuje wskazówek ${ }^{48}$, pouczeń ${ }^{49}$, uwag rządów gubernialnych ${ }^{50}$ co do sposobu opisywania strat w protokole ${ }^{51}$. Przykładowo 8-20 lipca 1852 roku RGL poucza NPŁ co do dokumentowania klęski allewiacyjnej, zaznaczając, że to protokół jest główną podstawą podjęcia decyzji o przyznaniu ulgi. Zwraca też uwagę na niedokładność sporządzanych protokołów wizji. Wskazuje, jakie dane powinny być w nim zawarte. Tu czytamy:

Co do klęsk gradobicia i wylewu wód, jakie zasiewy, a do jakiego gatunku ziarna, nie wyłączając kartofli, w dobrach klęską dotkniętych były zaprowadzone, czyli wszystkie zasiane pola klęską zostały dotknięte, lub jaka część tychże od klęski była wolną; z rozróżnieniem po jakiej ilości [...] wysiewy zostały zniszczone, a co do jakiej wolne od klęski pozostały ${ }^{52}$.

Protokoły różniły się od siebie, ale miały też elementy wspólne: określenie daty oględzin, daty i rodzaju klęski, szczegółowe określenie ilości utraconych zbiorów lub innych szkód ${ }^{53}$. Część urzędników wpisywała tu zeznania poszko-

4820 listopada-1 grudnia 1842 roku Rząd Gubernialny Podlaski w piśmie do Naczelnika Powiatu Łukowskiego wskazuje na braki w dotychczasowym sposobie prowadzenia śledztwa w sprawach allewiacyjnych. Przedstawia szczegółowe wytyczne, uzasadniając: „Gdy więc chcąc w przyszłości zasłonić strony poszkodowane od dalekiej zwłoki w odebraniu przypadać im mogącej bonifikacyi, która wypływa jedynie tylko z winy osób toż Śledztwo prowadzących, postanowił nie tylko obowiązujące dotąd przepisy tego przedmiotu dotyczące ponowić, ale nadto w niektórych Szczegółach bliższą W. Naczelnikom powiatowym udzielić informacyą". APL, NPŁ, sygn. 1, k. 45-46. Podobnie APK, NPK, sygn. 239, s. 83-84 (1844 rok).

49 13-25 sierpnia 1841 roku Rząd Gubernialny Podlaski przesłał do Komisarza Obwodu Łukowskiego wskazówkę, która dotyczyła sposobu formułowania akt przez delegowanych do tego asesorów: „[...] poleca najmocniej W Komisarzowi iżby do obliczenia spodziewanego dochodu i poniesionej straty używane były ceny zbóż i siana najbliżej przyległego dobrom poszkodowanym Miasta Targowego z przecięciu 12 ${ }^{\text {tu }}$ Miesięcy klęskę poprzedzających wynikłe tudzież iżby tenże wyciąg cen targowych za rzetelność przez W Kommissarza i za zgodność w rachubie przez jego Rachmistrza był poświadczany jak niemniej i wykaz intrat które na podstawie tychże cen ułożone być mają ostrzegając zarazem W Kommissarza iż w razie niezastosowania się w całej rozciągłości do niniejszego rozporządzenia Akta śledcze do ukompletowania na Koszt W Kommissarza zwracane będą", APL, NPŁ, sygn. 1, k. 38.

50 Rząd Gubernialny podlaski pouczał 19-31 sierpnia 1844 roku NPŁ o zasadach prowadzonego śledztwa: „Naczelnik Powiatu będzie obowiązany aby dopilnować spiesznego odbywania na Gruncie śledztw allewiacyjnych, bądź przez delegowanych do tey Czynności urzędników, bądź przez ościennych Wóytów Gmin iako też rychłego przestawienia akt śledczych allewiacyjnych Rządowi Gubernialnemu do dalszego postępowania". Ibidem, k. 47.

51 Ibidem, k. 73-76 (1862 rok); k. 45-46 (1842 rok), 47-48 (1844 rok), 58-62 (lata 18501852).

52 „Co do klęski pożaru, protokóła wizyi prócz opisu pozostałych budowli, obejmować powinny dokładne sprawdzenia na gruncie" — chodziło o zweryfikowanie, czy zebrane plony spłonęły i w jakiej części. APL, NPŁ, sygn. 1, k. 62.

53 Np. APŁ/S, NPW, sygn. 3, k. 30-32 (1850 rok). Podobnie k. 34-35; APL, NPŁ, sygn. 275, k. 15 (1863 rok), k. 78 (1865 rok).

Prawo 328, 2019

(C) for this edition by CNS 
dowanych i świadków, inni ograniczali się do opisywania własnych spostrzeżeń i zebrania podpisów poszkodowanych dla potwierdzenia wykazanych strat. W tym zakresie w aktach występuje różna forma, niekiedy straty zamieszczane były w tabeli ${ }^{54}$, innym razem był to opis ${ }^{55}$.

Protokoły różnią się też objętością. Niekiedy dokument zajmuje jedynie dwie strony $^{56}$, a innym razem kilkadziesiąt. Dużo zależało od liczby poszkodowanych wsi i doznanych przez nie strat. Niekiedy wyszczególniano dla jednej wsi kilkudziesięciu poszkodowanych gospodarzy, dodając krótkie zestawienie strat. Jeżeli protokół obejmował kilka wsi, jego objętość rosła. Protokół z 29 września 1849 roku zawierał tabelaryczne zestawienia strat wyrządzonych przez gradobicie ${ }^{57}$. Szkody do protokołu dyktował właściciel dóbr. Podane dane wpisywane były do tabel, które zawierały następujące kolumny: „Wysiew”, „Spodziewał się zebrać w ziarnie”, „Zebrał w snopie”, „Ile z tego zebrał w ziarnie”, ,Szkoda w ziarnie po potrąceniu od spodziewanego Plonu”, „Cena”, „Szkoda na pieniądze obliczona” i „Szkoda w ogóle”58. Następnie włościanie każdej wsi (Grabówka, Borowno, Grabowa, Borowne) podpisywali się pod szczegółowym wykazem strat. Tu również mamy utworzoną tabelę, która wymienia: „Nazwisko włościan”, „Co i ile wysiał”, ,Spodziewany plon w ziarnie”, „Ile zebrał w snopie”, „Ile z tego otrzyma ziarna”, „Szkoda w ziarnie po odliczeniu od spodziewanego plonu”, „Cena”, „Szkoda na pieniądze obliczona” i „Szkoda w ogóle”. Pod każdym zestawieniem widniał podpis gospodarza ${ }^{59}$.

W niektórych protokołach odnotowywano zeznania o wystąpieniu szkód. Niezależnie od formy ich udokumentowania podpisywali się poszkodowani, świadkowie i urzędnicy biorący udział w czynności ${ }^{60}$. Na koniec zamieszczano opinię delegowanego urzędnika, określającą ułamkowo, jaka część dochodu została utracona i czy jego zdaniem szkoda kwalifikuje się do allewiacji ${ }^{61}$.

2-14 czerwca 1850 roku kasjer miasta Mstowa delegowany przez naczelnika powiatu zjechał do Wsi Kłomnic i obejrzał wszystkie pola. Poniżej odnotował rezygnację z pretensji i podanie o zwolnienie tych ziem z ,inkwaterunku"62.

54 APŁ/S, NPW, sygn. 1, k. 123-133 (1849 rok).

55 APL, NPZ, sygn. 18, k. 15 (1843 rok); APŁ/S, NPW, sygn. 3, k. 30-32, 34-35 (1849 rok), 33 (1850 rok); APL, NPŁ, sygn. 275, k. 78, k. 89-90 (1865 rok).

56 Np. APL, NPZ, sygn. 18, k. 15 (1843 rok); APL, NPŁ, sygn. 275, k. 45 (1858 rok), 78 (1865 rok).

57 APŁ/S, NPW, sygn. 1, k. 124-133.

58 Ibidem, k. 124.

59 Ibidem, k. 125-133.

60 APŁ/S, NPW, sygn. 3, k. 30-32; APL, NPŁ, sygn. 275, k. 15.

61 Ibidem, k. 30-32; podobnie k. 34-35. APL, NPŁ, sygn. 275, k. 15 (1863 rok), k. 89-90 (1865 rok).

62 APŁ/S, NPW, sygn. 3, k. 33. 


\section{Wykaz opłaconych podatków i inne zestawienia}

Kolejnym dokumentem załączanym do akt był wykaz opłacanych podatków, przygotowywany na polecenie naczelnika powiatu przez kasę powiatu (kontrolera i poborcę) $)^{63}$. Naczelnik powiatu zobowiązany był do jego poświadczania ${ }^{64}$.

Władze gubernialne (przed 1837 rokiem wojewódzkie) wymieniały wykaz podatków wśród niezbędnej dokumentacji allewiacyjnej ${ }^{65}$. Niejednokrotnie upominały się o jego dołączenie. Rząd Gubernialny Lubelski pisał 30 maja-11 czerwca 1864 roku do NPŁ w sprawie gradobicia z 1862 roku, oczekując złożenia zestawienia podatków z folwarku nim dotkniętego w ciągu ośmiu dni. 5-17 czerwca 1864 roku NPŁ wezwał Kasę Powiatu Łukowskiego do dostarczenia brakującego dokumentu. Doręczony wykaz sporządzony został przez Kasę Powiatu Łukowskiego, wysłał go RGL ${ }^{66}$. Niekiedy w aktach była informacja o dostarczeniu wykazu podatków przez kasę. Dokumentu jednak brakuje ${ }^{67}$.

Wykaz miał formę tabeli zawierającej dane: oznaczenie dóbr, rodzaj podatku, rok, kwota podatku (wymiar), uwagi ${ }^{68}$. W przypadku większej liczby poszkodowanych osobno wpisywano dane dla każdego z nich, jak w dokumencie sporządzonym w 1858 roku przez Kasę Powiatu Łukowskiego dla 15 poszkodowanych ${ }^{69}$.

Poza wykazami opłaconych podatków do akt allewiacyjnych załączano też niekiedy inne dokumenty. Przykładem są rozmaite wykazy i wyciągi potwierdzające lub prognozujące dochody z dóbr, które doznały strat. W ZPAKP znajdujemy odpowiednie formularze: wyciąg intraty, wyciąg intraty rzeczywistej, wyciąg intraty spodziewanej ${ }^{70}$. Niekiedy natrafiamy na wyciąg intraty spodziewanej i rzeczywistej ${ }^{71}$ lub inne tabelaryczne zestawienia uposażeń i powinności ${ }^{72}$ czy wykazy cen ${ }^{73}$.

63 Obowiązek jego zamieszczenia pojawia się między innymi we wskazówce Rządu Gubernialnego Podlaskiego dla Naczelnika Powiatu Łukowskiego z 20 listopada-1 grudnia 1842 roku. APL, NPŁ, sygn. 1, k. 46. W praktyce pod wykazem podpisywali się kontroler i poborca kasy powiatowej. Np. APL, NPŁ, sygn. 275, k. 31-32 (1864 rok).

64 KRPiS: „Rozporządzenie: iż wykazy szczegółowe podatków, formowane przez wójtów gmin, mają być poświadczane przez Komisarzy Obwodowych” z 21 Lutego 1825 roku (ZPAKP, W.Sk., Allewiacje, s. 77-79).

65 Np. Komisja Województwa Podlaskiego w piśmie z 18 maja 1833 roku (APL, NPŁ, sygn. 1, k. 28).

66 APL, NPŁ, sygn. 275, k. 30-32.

67 Ibidem, k. 87.

68 Ibidem, k. 32 (1864 rok); 76 (1865 rok); 87 (1865 rok).

69 Wykaz opłaconych podatków za rok 1858 Kasa Powiatu 17 marca 1865 roku (APL, NPŁ, sygn. 275, k. 76).

70 ZPAKP, W.Sk., Allewiacje, załączone na końcu. Wzory przesyłane były również naczelnikom powiatu. Znajdujemy je między innymi w aktach kaliskich. APK, NPK, sygn. 239, s. 93-98.

71 APL, NPŁ, sygn. 275, k. 51-58.

72 Ibidem, k. 64-73 (1859 rok).

73 Ibidem, k. 59 (1858 rok).

Prawo 328, 2019

(C) for this edition by CNS 
Rząd Gubernialny Warszawski pisał do Naczelnika Powiatu Kaliskiego 29 grudnia 1949-10 stycznia 1850 roku, informując o brakach przy formułowaniu akt allewiacyjnych, które dla władz skarbowych niejednokrotnie stawały się podstawą do rekursów od wyroków sądu administracyjnego: ,przeto poleca Naczelnikom Powiatu aby odtąd przy nadsyłaniu Akt Śledczych w zamiarze przyznania allewiacyi, w podatkach za klęski losowe przez Właścicieli Dóbr doznawane Lustracje Intrat z r. 1789 składane były"74.

\section{Protokół odebrania przysięgi}

Dokument ten spisywano po złożeniu przysięgi przez poszkodowanych i świadków. Czynność ta powinna być wykonywana w zwykłym składzie wydziału spornego sądu pokoju, czyli podsędka i podpisarza. Przysięga miała potwierdzić złożone we wstępnym śledztwie zeznania i wskazać wartość poniesionych strat. W praktyce protokół spisywał pisarz lub podpisarz sądu pokoju. Podpisywał go podsędek. Od złożenia zeznań do odebrania przysięgi mijało kilka miesięcy, rzadziej parę lat ${ }^{75}$.

Prawo, określając rotę przysięgi, uzależniało formę jej wykonywania od wyznania. Instrukcje z 1833 i 1844 roku szczegółowo określały również okoliczności, na które należało wykonać przysięgę, rota zawierała szczegółowy opis strat, uratowanej części zbiorów, planowanych plonów itp. ${ }^{76}$

\section{Podsumowanie}

Śledztwo allewiacyjne wymagało dokumentowania podejmowanych czynności. Były one sporządzane na polecenie naczelnika powiatu, niejednokrotnie ponaglanego do działania przez rząd gubernialny.

Najważniejsze z nich dowodziły wszczęcia śledztwa, odbycia wizji na miejscu klęski i opisania powstałych szkód. Istotne z punktu widzenia władz okazały się też dowody potwierdzające opłacenie podatków, których miała dotyczyć ulga, jak również dodatkowe potwierdzenie strat już po zakończonych zbiorach.

Zadaniem tej dokumentacji było wykazanie, czy poszkodowany kwalifikuje się do allewiacji, to znaczy, czy w roku doznanej klęski opłacił podatek lub powi-

74 APK, NPK, sygn. 239, s. 116.

75 J. Machut-Kowalczyk, op. cit., s. 183-204.

76 APL, NPE, sygn. 1, k. 25-27; Podobnie art. 24, „Instrukcja do spraw allewiacyjnych przez Kommissyą Rządową Przychodów i Skarbu wydana w roku 1844”, nr 24, ZPAKP, W.Sk., Allewiacje, s. 123-130. Zob. J. Machut-Kowalczyk, op. cit., s. 183-204. 
nien był go opłacić i w jakiej wysokości. Ważne było wskazanie, czy poniesione straty przekraczają lub co najmniej są równe dwóm trzecim rocznego dochodu.

Dość częste ponaglanie, pouczanie, sugeruje, że NP nie zawsze należycie wywiązywali się z obowiązków. Widać duże zaangażowanie władz w nadzór nad odpowiednim dokumentowaniem śledztwa allewiacyjnego. Do poprawności opracowanej dokumentacji swoje zastrzeżenia zgłaszały nie tylko rządy gubernialne czy Komisja Rządowa Przychodów i Skarbu, ale również urzędnicy sądowi.

Wyniki badań zachęcają do prowadzenia dalszej kwerendy obejmującej również akta gubernialne i rządowe.

\section{Bibliografia}

\section{Źródła archiwalne}

Archiwum Państwowe w Kaliszu: Naczelnik Powiatu Kaliskiego (nr zespołu 1/0).

Archiwum Państwowe w Lublinie: Naczelnik Powiatu Zamojskiego (nr zespołu 127/0), Naczelnik Powiatu Łukowskiego ( $\mathrm{nr}$ zespołu 125/0).

Archiwum Państwowe w Łodzi, oddział w Sieradzu: Naczelnik Powiatu Wieluńskiego (nr zespołu $717 / 0)$.

\section{Źródła drukowane}

Zawadzki S., Prawo cywilne obowiąującem w Królestwie Polskiem, t. 2, Warszawa 1861.

Zbiór Przepisów Administracyjnych Królestwa Polskiego, Wydziat Skarbu, t. 2. Allewiacje, Warszawa 1866.

\section{Literatura}

Machut-Kowalczyk J., Przysięa $w$ śledztwie allewiacyjnym $w$ Królestwie Polskim $w$ świetle akt powiatowych wieluńskich, zamojskich i lukowskich, „Studia z Dziejów Państwa i Prawa Polskiego" 20, 2017, s. 183-204.

Witkowski W., Sądownictwo administracyjne w Księstwie Warszawskim i Królestwie Polskim 1807-1867, Warszawa 1984. 


\section{Documentation of alleviatory investigations (after a hailstorm or a flood) in the Kingdom of Poland on the basis of district heads' records until 1866}

Summary

Alleviatory investigations were conducted in $1842-1866$ by heads of districts. All important actions taken after a hailstorm or a flood were documented. The records included a report or request initiating the proceedings, site inspection protocols, lists of taxes paid, income gained, correspondence etc. The last group of documents comprised protocols of oaths taken before the magistrates' court (after the harvest). Proper documentation of investigations was controlled by higher level authorities. The records are full of recommendations, instructions and orders from governor and government bodies.

Keywords: Kingdom of Poland, alleviation, tax reliefs, alleviatory investigation

\section{Dokumentierung einer Untersuchung wegen Steuerermäßigung (nach Hagelschlag oder Überflutung) im Königreich Polen auf Grundlage von Akten der Kreisvorsteher bis 1866}

\section{Zusammenfassung}

Die Untersuchung betreffend Steuerermäßigung wurde in den Jahren 1842-1866 von dem Kreisvorsteher durchgeführt. Alle wichtigeren Handlungen, die nach einem Hagelschlag oder einer Überschwemmung vorgenommen wurden, wurden dokumentiert. $\mathrm{Zu}$ den Akten wurden der Bericht bzw. die das Verfahren einleitende Bitte, auch die Protokolle der Ortsbesichtigung, Aufstellungen der gezahlten Steuern, der erzielten Einkommen, der Korrespondenz usw. gelegt. Das letzte Dokument stellten die Protokolle des vor dem Friedensgericht geleisteten Eides (schon nach der Ernte) dar. Die entsprechende Dokumentierung der Untersuchung wurde durch höhere Behörden kontrolliert. Die Akten sind reichlich mit Anweisungen, Instruktionen und Aufträgen der Gouvernementsregierung und Regierungsorganen versehen.

Schlüsselworte: Königreich Polen, Steuerermäßigung, Untersuchung wegen Steuerermäßigung 